\title{
THE OPPORTUNITY COST OF THE UPKEEP OF THE CRIMINAL JUSTICE SYSTEM IN SOUTH AFRICA FROM 1980 TO 2006
}

\author{
Pierre de Villiers
}

Department of Economics, University of Stellenbosch

Soon Nel

Department of Accountancy, University of Stellenbosch

Accepted November 2009

South African crime rates rose to unacceptably high levels between 1980 and 2006. As a result, vast amounts of funds were devoted to the upkeep of the criminal justice system - correctional services, justice and the police. Although it is necessary to spend a certain amount on the criminal justice system, South African expenditure was excessive. The excess funds spent on the upkeep of the criminal justice system could have covered the cost of financing the entire backlog in schooling facilities and a large part of the current housing shortage.

JEL DoO, E62, H10, 40

1

\section{Introduction}

One of the most agonising problems South Africa currently faces is the high incidence of crime and the accompanying general sense of lawlessness. The aim of this paper is to establish the magnitude of the impact of crime on the South African economy and to show that this has been substantial.

The first contribution of this study is that it compares South Africa's crime situation with that in other countries. The second is that it quantifies the excess expenditure on the criminal justice system. The former presents a challenging exercise, as in 2000 the government placed a moratorium on the release of South Africa's crime statistics, and there is currently a drive to reinstate another moratorium, making the relevant information difficult to obtain (Eyewitness News, 2009). Despite the difficulty in obtaining the information, it is necessary to establish how South Africa fares in comparison with its international counterparts. This would establish whether South Africa's situation was dire or merely within acceptable norms.
Quantification of the excess expenditure on the South African criminal justice system, which, as the literature review reveals, has not been carried out before, affords the opportunity of reflecting on the magnitude of the foregone expenditure on social services, an important variable in the progress of a developing country. It is important to note that this study does not regard all expenditure on the criminal justice system as excessive. Although it is a taxing exercise, its aim is to first show that part of the expenditure has been excessive and then to quantify that excess. Expressing the latter in terms of foregone opportunities, such as the schools and houses that could have been built, will highlight the extent to which crime in South Africa has hampered the progress of this developing country. Schooling and housing were selected because empirical research has indicated that they are the two most significant economic and socio-economic explanatory variables in combating crime.

The first section of this paper will establish what crime entails and how standard economic theory encapsulates the determinants of crime. The South African crime situation will be compared with that in other countries. It will be shown that the crime rate in South Africa is 
high by global standards. In the second section, the direct economic implications of crime will be discussed. For the purposes of this paper, the direct economic implications of crime will be defined as government expenditure on the criminal justice system. It will be shown that, for the period 1980-2006, government expenditure on the upkeep of the criminal justice system was excessive. These excessive costs will be quantified and an opportunity cost figure will be calculated in terms of foregone expenditure on social services like housing and education.

\section{2}

\section{Theory and global perspective on crime}

\subsection{Introduction}

What constitutes criminal behaviour? In this section it will be shown that there is no universal definition of crime. The extent of the crime situation in South Africa and the level of domestic crime in comparison with that in other countries will be investigated to determine how South Africa measures up to its international counterparts.

\subsection{Defining crime}

Criminologists disagree about the exact definition of crime. One of the main reasons for this appears to be their attempt to derive a definition of crime that applies to all societies. The word 'crime' is derived from the Latin word crimen, which means "reproach" or "accusation" (Harries, 2007:5). But what exactly does crime entail and where does it originate? Anthropologists have been struggling for years to pinpoint the exact nature of crime. This is partly because it is determined largely by culture. In other words, while certain actions may be regarded as criminal in one culture, they would not necessarily be viewed as criminal in another. While the consumption of wine is regarded as a crime in Saudi Arabia, this is not the case in South Africa. Nor does the view of crime remain constant within a given culture. In South Africa, for example, same-sex marriages were regarded as a crime until they were legalised in 2006. Despite these variations, criminal behaviour can be regarded as such only if this behaviour is comparable with a criminal yardstick, i.e. if the nature of crime is precisely defined.

The most commonly applied definition of crime is expressed in legal terms. An act is considered a crime only when it is prohibited by criminal law and violates the prevailing legal code of the jurisdiction in which it occurs (Munchie, 2001:10). According to Williams (2001:12), an act constitutes a crime if it involves any harm incurred to society, breaches a legal rule and is subject to legal punishment, i.e. if it violates the criminal law. Hence the yardstick for determining whether or not an act is a crime is the criminal law of any specific country. As criminal law includes the informal norms of a given society, it follows that the nature of criminal law differs from one society to another. In Holland, dealing in marijuana is viewed rather leniently, while it is punishable by death in Malaysia. As these informal social norms change, so does a country's criminal law.

Where does criminal law originate? Criminal law can be viewed as the social consensus of a given society on what behaviour is generally acceptable and what behaviour is punishable by the state. However, as used to be the case in South Africa, criminal law can also serve the interests of select groups. For decades, industrial, mining and agricultural institutions aligned themselves with the apartheid government in South Africa to exploit black labour (Lowenberg \& Kaempfer, 2001:1). Laws like the Native Labour Act and the Group Areas Act were passed to safeguard the interests of the ruling capitalist class.

For the purpose of this paper, crime will be regarded as the result of the interplay of society's political, economic and social aspects. Regardless of the exact nature of the problem, criminal policy-makers have to carefully consider the key factors that drive South Africa's high crime rates. To this end, it is crucially important to understand the underlying economic theory of crime in South Africa. 


\subsection{Economic theory of crime and punishment}

Becker (1968) was the first economist to attempt an explanation of criminal behaviour within the context of economic theory. According to Becker, criminals are utility maximisers who divert their time to legal and illegal activities. Potential criminals consider various employment opportunities and generally opt for the opportunity that yields the highest return. In other words, they are driven by rational choice.

According to Luiz (2001:35), rational criminals consider the marginal return from criminal activities vis-à-vis the marginal return from legal employment opportunities. If the net benefit of criminal activities over legitimate activities exceeds the penalty when caught, they are inclined to opt for criminal activities.

In a similar vein, Brown $(2001: 273)$ refers to a cost benefit exercise that would-be criminals go through when considering criminal activities vis-à-vis legitimate forms of employment. She concludes that criminal patterns of thought are more rational than is generally expected. Potential criminals compare the payoff between criminal and legitimate activities and, if there is a substantial differential, i.e. if the return from committing the crime exceeds the return from more legitimate pursuits, the inclination to commit the crime increases. The conventional approach to combating crime has consequently focused on increased expenditure on the criminal justice system.

Becker (1968:191-196) was also concerned about the optimum expenditure on crime, which would depend on the way in which criminals are punished. Should they be fined or sent to jail? Probation and institutionalism require, inter alia, resources for guards and supervisors. This means that the community has to bear part of the cost. Fining criminals makes economic sense where the fine equals the sum of the marginal harm caused by the offender and the cost of apprehending him, in which case, fines merely equate to transfer payments. However, this fosters an environment in which illegal behaviour can be bought off at a price, as long as the would-be offender can afford the fine. It also assumes that the marginal cost of a crime is known, which in reality, is rarely the case.

\subsubsection{Expenditure on the criminal justice system}

Given criminals' rational thought processes and their aversion to being caught, the conventional approach to combating crime is to raise the costs associated with committing crime, i.e. increase expenditure on the criminal justice system in order to increase the possibility that criminals will be apprehended, convicted and punished (Blackmore, 2003:444). This approach has seen expenditure on the South African criminal justice system increase from 0.7 per cent of GDP in 1980 to 2.6 per cent in 2006 .

However, there is a growing body of evidence that this is not the most effective policy vehicle for combating crime. The international perspective on the interaction between crime, criminal justice and poverty reduction is changing. The World Bank and the United Nations Development Programme are reconsidering their funding policies for criminal justice reform. Empirical evidence provided by Blackmore (2003) supports this approach in its conclusion that expenditure on the South African criminal justice system is not the most important variable in deterring crime. ${ }^{1} \quad$ Blackmore (2003) analysed 10 independent variables in relation to 15 types of crime, including expenditure on the criminal justice system, which he found to be the least significant explanatory variable. Despite Blackmore's failure to deal satisfactorily with endogeneity, Brown (2001) concurs that expenditure on the criminal justice system is not the best policy vehicle for deterring crime. This was confirmed in a study by Stone (2006), who concluded that expenditure on the criminal justice system contributes very little to combating crime and in some cases may even exacerbate the problem. Some authors even exclude government expenditure on the criminal justice system, which is probably the most visible policy tool, as an explanatory variable in their empirical work (Demombynes \& Özler, 2002).

Given South Africa's history over the past 28 years, it would be difficult to regard the 
criminal justice system as an efficient and effective deterrent of crime. But if expenditure on the criminal justice system is not the most efficient way of combating crime, what are the most significant determinants of crime?

\subsubsection{Determinants of crime}

Earlier researchers, such as Becker (1968:174177), focused on the number of criminal offences as a function of the probability of being convicted, the magnitude of the punishment if convicted, the income available in legal and illegal activities, the frequency of arrests and the willingness to be involved in criminal activities. Becker argued that offenders are deterred more by the probability of being caught than by the punishment itself. Non-premeditating murderers and robbers, for example, act on impulse and are therefore unresponsive to the size of the punishment (Becker 1968:186-189).

Many authors have since refuted the theory that expenditure on the criminal justice system is the best deterrent to crime, and the focus has subsequently shifted in other directions. Buonanno (2003) summarises the findings of several international studies, stating that criminal behaviour is determined by the probability of being caught and apprehended, the difference between wages in legal and illegal activities, unemployment, levels of education, family background, cultural characteristics, age and gender. Criminals are typically young people with low levels of education, who have grown up in disadvantaged communities and who are frequently unemployed (Buonanno, 2003). The socio-economic status of individuals therefore seems to play an important role in the decision to partake in criminal activities.

In a similar study in South Africa, Luiz (2001) found that criminals are typically young people with low levels of education, low prospects of legitimate earning and low test scores. Areas with higher unemployment and greater inequality result in higher crime rates. Luiz also found that many young people combine criminal and legal employment activities. Similarly, Brown (2001) contended that economic and socio-economic variables are important determinants of crime. She concluded that economic variables are the most significant determinants of crime, with education being the most important of these variables.

An interesting finding by Blackmore (2003) was that the most important demographic factors were the degree of urbanisation and the ratio of women to men. Although Blackmore failed in his empirical research to deal with endogeneity, his findings correlate positively with international research results indicating that unemployment, low levels of education, inequality, low socio-economic standing and age are positively linked to crime rates (Buonanno, 2003). Therefore the solution to crime in South Africa appears to lie in an interdisciplinary approach, including various social, economic, political and lawenforcement factors.

\subsubsection{Implications for economic growth}

In many countries, government expenditure on the criminal justice system is the main direct cost associated with crime. In South Africa, however, businesses seem to bear the brunt of these direct costs. According to the South African Institute of Race Relations (2006:507), the number of employees in the private security sector rose by 150 per cent between 1997 and 2005. In 2005 there were no less than 2.7 private security officers for every sworn police official. The World Bank's Investment Climate Survey (Clark et al., 2005:95-98) estimates the costs of crime in South Africa at approximately 1.1 per cent of businesses' sales. How do these cost implications for private-sector businesses impact on economic growth?

The general perception is that crime hampers growth because it diverts resources away from productive activity to protection efforts (Demombynes \& Özler, 2002). Crime is also a major contributing factor to the emigration of professional skills and discourages investment, which inhibits longterm growth. Research by Van Rooyen (2000) indicates that violent crime is the reason for 60 per cent of emigrants leaving the country. Similar findings are reported by Bezuidenhout et al. (2009), who found that 76 per cent of doctors who emigrated rated the high crime rate as the most important reason other than financial considerations. 
According to Stone (2006), there are seven crime-related factors that may restrain economic growth. First, businesses suffer direct losses and have to incur costs to enhance security measures. The diversion of funds from more productive operational activities reduces profits. For example:

1) The cost of motor claims in the insurance industry accounts for approximately 30 per cent of all insurance claims paid out (SA's short-term insurance industry contributes to the fight against crime, 2006);

2) Governments have to spend more on law enforcement, curtailing funds for other, more productive, uses;

3) Households tend to spend more on security measures and health care than they do on school fees and other investments of a more productive nature;

4) Crime injures, destroys or erodes human capital through the emigration of highly sought-after professional skills;

5) Crime prevents people from entering the labour market when this entails working after hours or far from home;

6) Crime discourages foreign investment; and

7) Crime disrupts efforts in support of economic growth. For example, crime may prevent learners from attending school and employees from using public transport to get to work, both of which activities contribute to economic growth.

Stone (2006) presented these seven factors in two main hypotheses. The first states that crime imposes direct and indirect costs on businesses, eroding their profits and hampering investment. According to the second hypothesis, economic growth is hampered by limiting investment, work and leisure activities and discouraging tourism.

Further, crime in South Africa indirectly constrains growth by creating the perception of instability, especially considering the prevalence of violent crime. The World Bank's Investment Crime Survey (Clark et al., 2005:88) suggests that 30 per cent of South African businesses regard crime as a major constraint to investment. Businesses lose production time and profits by incurring losses from robbery and excessive expenditure on crime prevention. This discourages economic growth, since businesses may limit their investment on account of the perceived risk associated with crimes like robbery. Households are forced to increase expenditure on security measures, which inhibits schooling outcomes, since households consequently spend less on schooling. Crime therefore reduces investment in human capital. Others choose to emigrate, resulting in the loss of human capital, which quite often results also in physical capital outflow. Alternatively, workers may be kept away from their work place as a result of injury or murder.

Although economic growth is important, criminal policy should be aimed at reducing crime rather than pursuing economic growth. A clear grasp of the determinants of crime is crucially important to ensure that the South African government achieves this goal.

But exactly how serious is the problem of crime in South Africa, and how does the situation compare internationally? In the next section South Africa's crime statistics will be analysed and compared with those of other countries.

\subsection{The magnitude of crime in South Africa compared to the rest of the world}

Does South Africa really have a major crime problem? And is the situation becoming worse, or are matters actually improving? The correct answer may be elusive. An increase in the number of crimes reported is not necessarily an indication that the situation is deteriorating. The efficiency of the criminal justice system could have improved to the extent that certain crimes are reported and combated more efficiently. By the same token, a drop in the number of reported crimes could be the result of the deteriorating efficiency of the criminal justice system. According to a Nedcor crime survey (in Brown, 2001:270) official crime statistics may underestimate actual incidences of crime by as much as 50 per cent. Rape Crisis estimates that only one in every 35 rape cases is reported (Nedcor crime survey, quoted in Brown, 2001). Crime statistics do, however, indicate the broad patterns of crime.

On average, South Africans were subjected to the following reported crime rates over 
the period 1 April 2002 to end-March 2007: Someone was raped every 10 minutes, a murder or attempted murder occurred approximately every 9 minutes, a robbery occurred approximately every 2.5 minutes. Somewhere in South Africa someone was assaulted in almost every minute of every day. Every 90 seconds someone's premises (home or work) were burgled. Every 36 seconds something was stolen. In total, a serious crime occurred every 12 seconds during the period 1 April 2002 to 31 March 2007 (Institute for Security Studies, 2007). As was indicated in Section 2.3 there were 2.7 private officers for every sworn police official in 2005. Without the existence of the private security industry the crime statistics would probably have been worse.

Table 1

Crime ratios per 100000 of the population for selected countries: 2002

\begin{tabular}{|c|c|c|c|c|c|c|}
\hline Country & Murder & Rape & Assault & $\begin{array}{c}\text { Theft } \\
\text { (All kinds) }\end{array}$ & Fraud & $\begin{array}{c}\text { Drug } \\
\text { Offences }\end{array}$ \\
\hline \multicolumn{7}{|c|}{ High Income - non-OECD } \\
\hline Cyprus & 1.44 & 0.26 & 74.64 & 95.04 & 0.39 & 17.25 \\
\hline Kuwait & 5.02 & - & 116.03 & 364.87 & 7.39 & - \\
\hline Saudi Arabia & 0.77 & 1.38 & 5.46 & - & - & 5.74 \\
\hline Slovenia & 2.49 & 7.84 & 95.21 & 211.46 & 69.86 & 30.96 \\
\hline \multicolumn{7}{|c|}{ High Income - OECD } \\
\hline Australia & 2.35 & 8.06 & 15.92 & 25.56 & 5.62 & 10.25 \\
\hline Austria & 3.76 & 7.77 & 434.62 & 3743.46 & 428.07 & 278.6 \\
\hline Belgium & 27.58 & 51.5 & 839.23 & 923.73 & 170.65 & 452.35 \\
\hline Canada & 3.32 & 19.75 & 406.26 & 256.83 & 68.88 & 133.07 \\
\hline Czech Republic & 2.24 & 4.21 & 67.65 & 310.41 & 206.83 & 20.53 \\
\hline Denmark & 0.61 & 1.25 & 102.94 & 280.92 & - & 9.88 \\
\hline Finland & 4.25 & 1.52 & 217.49 & 599.66 & 98.83 & 145.01 \\
\hline Germany & 1.43 & 3.17 & 42.88 & 236.4 & 164.47 & 64.04 \\
\hline Iceland & 2.46 & 2.82 & 81.69 & 185.21 & 48.24 & 103.52 \\
\hline Ireland & 1.29 & 1.77 & 145.29 & 204.58 & 54.46 & 31.71 \\
\hline Italy & 12.63 & 6.46 & 65.49 & 127.85 & 39.02 & 84.73 \\
\hline Japan & - & 1.97 & 16.76 & 4.56 & 9.29 & 18.48 \\
\hline Korea, Rep. & 1.64 & 3.86 & 359.09 & 33.22 & 147.3 & 12.42 \\
\hline Luxembourg & 2.71 & 1.8 & 62.61 & 125.68 & 11.26 & 24.77 \\
\hline Netherlands & 0.06 & 5.82 & - & 35.49 & 58.9 & 88.84 \\
\hline New Zealand & 3.07 & 11.22 & 390.84 & 417.26 & 83.89 & 209.6 \\
\hline Portugal & 11.22 & 0.89 & 143.4 & 161.71 & 30.55 & 37.21 \\
\hline Sweden & 4.02 & 2.82 & 131 & 307.12 & 56.46 & 194.12 \\
\hline Switzerland & 2.5 & 1.4 & 29.68 & 155.79 & 42.52 & 103.2 \\
\hline United Kingdom & 2.22 & 5.02 & 255.97 & 373.38 & 37.48 & 97.32 \\
\hline United States & 8.87 & 32.99 & 310.14 & 4739.15 & - & - \\
\hline
\end{tabular}




\begin{tabular}{|c|c|c|c|c|c|c|}
\hline \multicolumn{7}{|c|}{ Upper Middle Income } \\
\hline Argentina & 22.16 & 8.32 & 853.18 & 2348.18 & - & 42.51 \\
\hline Chile & 7.91 & 5.4 & 222.55 & 493.07 & 46.19 & 10.91 \\
\hline Costa Rica & 26.68 & 16.06 & 57.94 & 1320.67 & 54.06 & 27.88 \\
\hline Croatia & 5.11 & 1.52 & - & 159.19 & 66.22 & 112.72 \\
\hline Hungary & 4.15 & 5.89 & 192.77 & 2188.54 & 306.16 & 47.11 \\
\hline Latvia & 7.48 & 2.31 & 82.68 & 837.39 & 162.01 & 21.39 \\
\hline Lithuania & 10.44 & 4.9 & 42.29 & 429.75 & 13.29 & 16.58 \\
\hline Mexico & 2.23 & 1.77 & - & 30.77 & 7.81 & 9.77 \\
\hline Oman & 1.3 & 4.37 & 36.84 & 56.74 & 7.84 & 16.04 \\
\hline Panama & 9.56 & 7.21 & 200.99 & 466.22 & 8.88 & 50.48 \\
\hline Romania & 7.15 & 4.23 & 20.7 & 266.62 & 22.2 & 1.57 \\
\hline Slovak Republic & 121.73 & 3.25 & 179.21 & 425.64 & 109.59 & 16.94 \\
\hline South Africa & 151.31 & 115.61 & 1797.7 & 3632.94 & 124.01 & 118.67 \\
\hline Turkey & 6.31 & 2.42 & 2.78 & 9.78 & 1.5 & 4.17 \\
\hline Uruguay & 13.78 & 9.02 & 451 & 3007.58 & 95.03 & 25.5 \\
\hline Venezuela & 2.31 & 0.61 & 0.43 & 6.96 & 0.43 & 3.88 \\
\hline \multicolumn{7}{|c|}{ Lower Middle Income } \\
\hline Albania & 17.21 & 3.87 & 13.65 & 63.05 & 6.22 & 9.94 \\
\hline Azerbaijan & 2.98 & 0.32 & - & 15.84 & 8.12 & 24.17 \\
\hline Belarus & 12.3 & 4.29 & - & 227.44 & 22.16 & 28.57 \\
\hline El Salvador & 21.59 & 38.38 & 245.04 & 224.92 & 51.94 & 22.92 \\
\hline Maldives & 8.36 & - & 98.61 & 149.47 & 16.73 & - \\
\hline Moldova & 11.1 & 5.52 & 3.1 & 4.53 & 2.94 & 0.19 \\
\hline Morocco & 7.53 & 4.12 & 661.57 & 21.64 & 101.79 & 8.08 \\
\hline Namibia & 8.26 & 14.41 & - & 3.02 & - & - \\
\hline Peru & 39.46 & 22.84 & 33.74 & 66.78 & 5.78 & - \\
\hline Philippines & 26.49 & - & 2.65 & - & - & - \\
\hline Tunisia & 2.91 & 3.13 & 517.45 & 367.97 & 25.65 & 8.33 \\
\hline \multicolumn{7}{|c|}{ Low Income } \\
\hline Afghanistan & 1.69 & 0.94 & 0.6 & 4.37 & 0.83 & 0.47 \\
\hline Ethiopia & 20.04 & 5.98 & 114.15 & 55.68 & 13.7 & 0.43 \\
\hline Myanmar & 3.68 & 1.17 & 21.48 & 10.97 & 4.78 & 4.72 \\
\hline Nepal & 5.98 & 1.24 & 0.54 & 9.13 & 1.56 & 1.24 \\
\hline
\end{tabular}

Source: United Nations Office on Drugs and Crime, 2004.

How does South Africa's crime situation compare with that of its international counterparts? Although local crime statistics for 2007 are available, comparable international crime statistics are not readily so. The most recent international crime statistics available for comparison are the figures for 2002. After comparing South Africa to the 55 other countries in Table 1, a 'top three' list was compiled for each of the six categories of crime in Table 2. To the best of the authors' knowledge, no such comparison has been carried out before. This being the case, the results contribute to a greater understanding of the nature and magnitude of the crime situation in South Africa in comparison with the rest of the world. When compared to countries in the middle and lower income brackets, which is where South Africa is categorised economically, South Africa tops the list in every one of these six categories except fraud, where South Africa is placed third. 
Table 2

Countries with highest crime ratios: 2002 (High income countries excluded)

\begin{tabular}{|c|c|c|c|c|c|c|}
\hline & Murder & Rape & Assault & $\begin{array}{c}\text { Theft } \\
\text { (All kinds) }\end{array}$ & Fraud & Drug Offences \\
\hline 1 & South Africa & South Africa & South Africa & South Africa & Hungary & South Africa \\
\hline 2 & Slovak Republic & El Salvador & Argentina & Uruguay & Latvia & Croatia \\
\hline 3 & Peru & Peru & Morocco & Argentina & South Africa & Panama \\
\hline
\end{tabular}

Source: United Nations Office on Drugs and Crime, 2004.

When the 2002 figures are compared with those of 1994 it is clear that there has been no improvement with the new democratic dispensation, apart from the fraud category, in which South Africa dropped from second to third place. Since 1994 South Africa's position deteriorated for each of the other five categories. South Africa's crime problem has clearly not abated and the country's criminal justice system faces increasing pressure in terms of high crime rates and huge prison populations (Frost in Brown, 2001:281). South Africa's situation deteriorated despite expenditure on the criminal justice system increasing from 1.9 per cent of GDP in 1994 to 2.4 per cent of GDP in 2002 .

Table 3

Countries with highest crime ratios: 1994 (High income countries excluded)

\begin{tabular}{|r|l|l|l|l|l|l|}
\hline \multicolumn{2}{|c|}{ Murder } & \multicolumn{1}{|c|}{ Rape } & \multicolumn{1}{|c|}{ Assault } & \multicolumn{1}{|c|}{$\begin{array}{l}\text { Theft } \\
\text { (All kinds) }\end{array}$} & \multicolumn{1}{|c|}{ Fraud } & Drug Offences \\
\hline 1 & Rwanda & Rwanda & South Africa & South Africa & Hungary & Mauritius \\
2 & South Africa & South Africa & Botswana & Botswana & South Africa & South Africa \\
3 & Honduras & Botswana & Zimbabwe & Poland & Mauritius & Zimbabwe \\
\hline
\end{tabular}

Source: Crime information management centre, 1994:1-4.

Nor does South Africa's situation improve dramatically when a top-three list is compiled for all 56 countries, including high income countries. Although South Africa drops to seventh and eighth place for fraud and drug offences respectively, it again tops the list for murder, rape, assault and theft. Figure 1 provides a scatter graph of logged Gross National Income per capita and total crime rates per 100000 of the population.

South Africa falls below the trend line in Figure 1 and emerges as the furthest point to the right on the graph, which confirms the country's alarming crime rates when it is compared internationally. South Africa has the highest crime rate of all the countries in Table 1, irrespective of their per capita Gross National Income. Crime has clearly become a major problem in South Africa. In the next section it will be demonstrated that the current situation in South Africa is untenable and that combating crime is extremely costly. 
Figure 1

Total crime rates and logged Gross National Income per capita (2002)

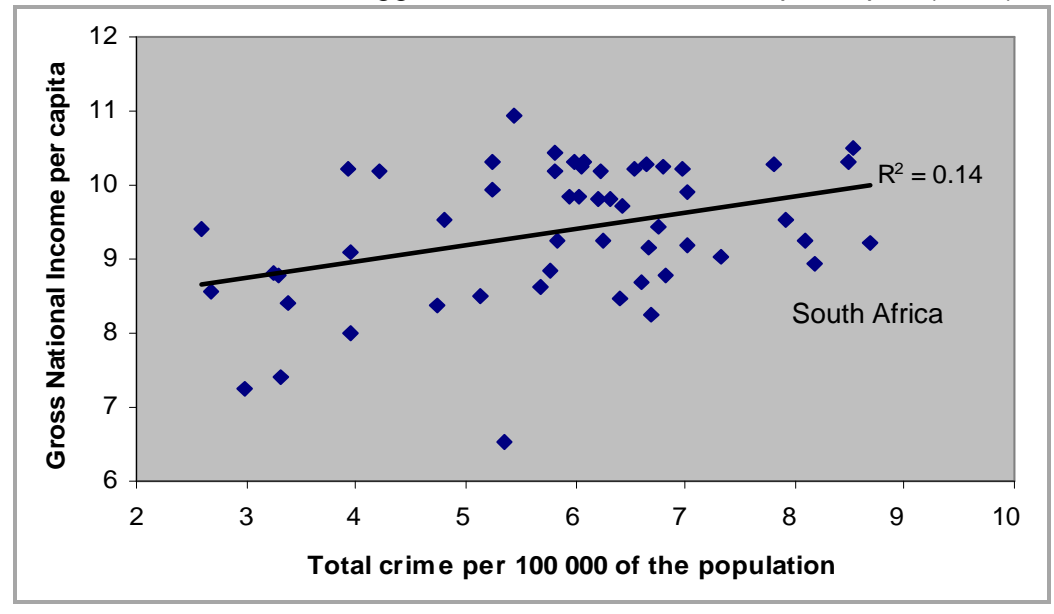

Source: Institute for Security Studies, 2007 and The World Bank, 2006.

3

\section{Direct costs of crime}

\subsection{Introduction}

The main emphasis in this section is on excess government expenditure on the criminal justice system. It will be shown that the direct economic cost implications of crime for the period 1980-2006, i.e. government expenditure on the police services, correctional services and the justice system, were substantial. Two yardsticks will be used to determine the excessive extent of this expenditure: an inflation scenario and a social services scenario. These scenarios are discussed in more detail in sections 3.3.2 and 3.3.3. It will be demonstrated that substantial opportunity costs have been involved on both counts. Much of South Africa's current dilemma relating to the insufficient provision of social services could perhaps have been prevented had these funds been allocated differently.

\subsection{Direct economic costs}

There can be little doubt that crime imposes costs on an economy, but an attempt to accurately measure the direct cost implications of crime is not really possible. Direct private costs could include, inter alia, the following: expenditure on fire arms, insurance, value of goods lost, loss of productivity through injury, the loss of revenue by the state as a result of illegal enterprises and security measures such as burglar proofing and alarm systems. ${ }^{2}$ All these costs impact negatively on the economy, but an attempt to isolate that percentage of the private costs directly attributable to crime is a taxing - if not impossible - exercise, and at present no such information on South Africa is available. For this reason, the authors have not included an estimate of direct private costs in their calculations. However, there are certain costs that can be clearly identified.

The most visible direct cost incurred by state expenditure is that for the upkeep of the criminal justice system, i.e. police services, correctional services and the justice system itself. In an attempt to fully understand the economic implications of crime in South Africa, reference must be made to the resources allocated to these three departments. As indicated in Table 4, R409 million was spent in 1980 on the upkeep of the criminal justice system. This was equivalent to 0.7 per cent of nominal GDP. In the 1994/95 budget year (the first year of the democratic South Africa), about R9.5 billion was spent on the upkeep of the criminal justice system (South African Report, 1980 and 1995). By 2006/07 this amount had further increased to approximately R45.2 billion or 2.6 per cent of nominal GDP (National Treasury, 2007). The question remains, however, as to whether these costs are excessive and, if so, to what extent. 
Table 4

Government expenditure on the criminal justice system: 1980-2006 (R'000)

\begin{tabular}{|c|c|c|c|c|}
\hline Year & Police & Correctional Services & Justice & \multicolumn{1}{c|}{ Total } \\
\hline 1980 & 260528 & 99793 & 48874 & 409195 \\
\hline 1981 & 321265 & 122618 & 53609 & 497492 \\
\hline 1982 & 379050 & 134305 & 62602 & 575957 \\
\hline 1983 & 510632 & 200575 & 91580 & 802787 \\
\hline 1984 & 602282 & 241326 & 140906 & 984514 \\
\hline 1985 & 863659 & 338762 & 146021 & 1348442 \\
\hline 1986 & 996922 & 359898 & 186455 & 1543275 \\
\hline 1987 & 1237952 & 408190 & 211642 & 1857784 \\
\hline 1988 & 1580345 & 520203 & 241049 & 2341597 \\
\hline 1989 & 1979926 & 636930 & 280989 & 2897845 \\
\hline 1990 & 2546350 & 753835 & 363955 & 3664140 \\
\hline 1991 & 3371740 & 934727 & 492733 & 4799200 \\
\hline 1992 & 4734789 & 1282472 & 628410 & 6645671 \\
\hline 1993 & 5931043 & 1540931 & 862697 & 8334671 \\
\hline 1994 & 6743925 & 1763907 & 1018573 & 9526405 \\
\hline 1995 & 7346313 & 2160822 & 1281808 & 10788943 \\
\hline 1996 & 9817900 & 2748000 & 1404800 & 13970700 \\
\hline 1997 & 11634700 & 3424500 & 1772400 & 16831600 \\
\hline 1998 & 12843954 & 3962300 & 2209722 & 19015976 \\
\hline 1999 & 13934698 & 5036096 & 2325302 & 21296096 \\
\hline 2000 & 14572459 & 5145367 & 2654385 & 22372211 \\
\hline 2001 & 15597445 & 5474924 & 2737651 & 23810020 \\
\hline 2002 & 17670435 & 6549171 & 3933456 & 28153062 \\
\hline 2003 & 19713543 & 7068475 & 4484857 & 31266875 \\
\hline 2004 & 22692887 & 7849714 & 4966118 & 35508719 \\
\hline 2005 & 25414522 & 8828792 & 5499366 & 39742680 \\
\hline 2006 & 29360784 & 9631216 & 6193636 & 45185636 \\
\hline Total & 232660596 & 77217849 & 44293596 & 354171493 \\
\hline
\end{tabular}

Source: South African Report, 1980-1997, Department of Finance, 1998-2000 and National Treasury, 2001-2007

The South African Police Service (SAPS), the most expensive of the three components of the criminal justice system, absorbed on average approximately two-thirds of the total cost of the criminal justice system for the period 19802006 (South African Report, 1980-1997, Department of Finance, 1998-2000; National Treasury, 2001-2007). Government expenditure on the SAPS increased substantially during the period 1980-1994 (e.g. by 43 per cent in 1985 when the state of emergency was declared). On average it increased by 11.1 per cent in real terms. From 1994-2006 the growth rate dropped to 6.7 per cent per annum in real terms. Expenditure on the SAPS increased from R261 million in 1980 to R29.4 billion in
2006 (equal to an annual real growth rate of 8.9 per cent).

Government expenditure on correctional services increased steadily over the entire period. For the period 1980-1994, expenditure increased annually at a growth rate of 7.8 per cent in real terms and from 1994-2006 by 8.7 per cent per annum. For the period 19802006, government expenditure on correctional services increased from R100 million to R9.6 billion - equal to an annual real growth rate of 8.2 per cent.

During the period 1980-1994, government expenditure on the justice system increased at a moderate rate (except for 1983 and 1984 when it grew by 30.4 per cent and 37.8 per 
cent respectively in real terms), averaging a real growth rate of 9.1 per cent per annum. During the period 1994-2006 the real growth rate increased moderately to 9.6 per cent per annum. From 1980-2006, the average real growth rate was 9.4 per cent per annum. Government funding of the justice system increased from R49 million in 1980 to R6.2 billion in 2006.

Real per capita expenditure (in constant 2000 prices) on the upkeep of the criminal justice system increased from only R138 in
1980 to R712 in 2006 - the equivalent of an increase of 413 per cent for the entire period or an average growth rate of 6.5 per cent per annum (Statistics South Africa and information in Table 4). The exponential growth in real per capita expenditure is illustrated in Figure 2. Total expenditure on the upkeep of the criminal justice system in 2006 was 110 times higher than in 1980. Despite the drastic increase since 1980, this has not had the desired effect of decreasing the crime rates.

\section{Figure 2}

Real per capita expenditure (in 2000 prices) on the upkeep of the criminal justice system in South Africa: 1980-2006

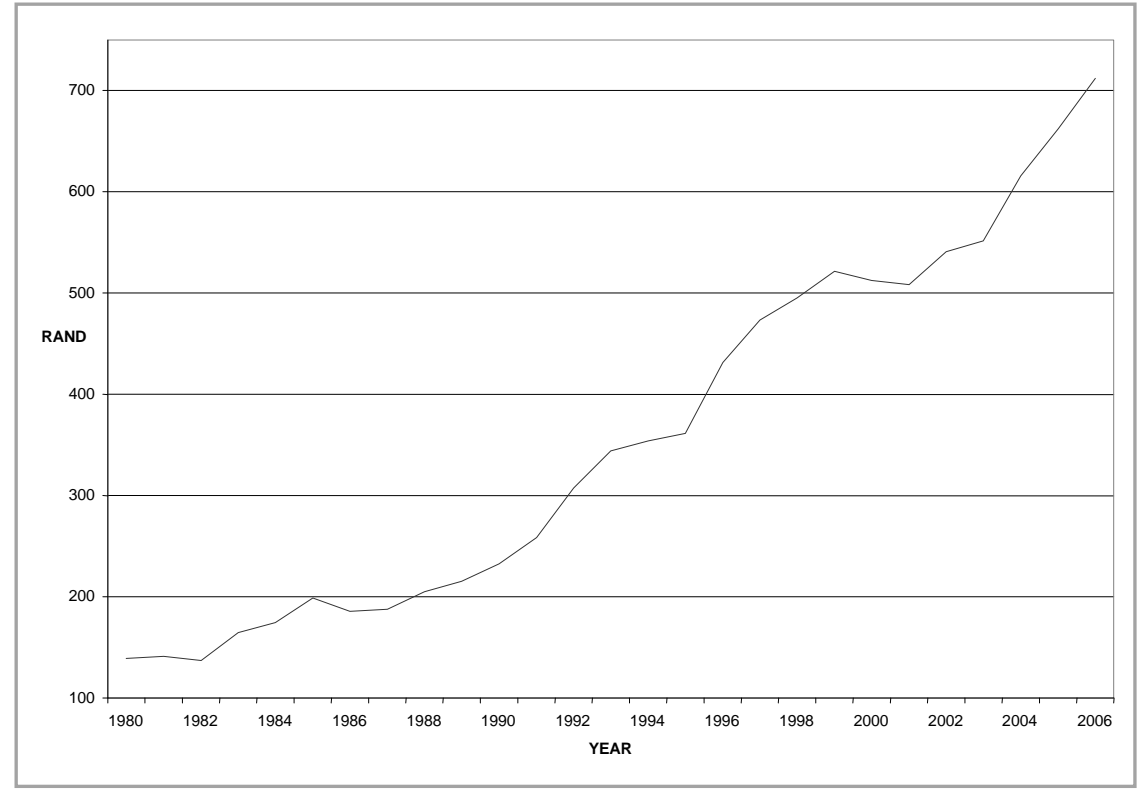

Has too much been spent on the upkeep of the criminal justice system? If so, exactly how much has been lost? Could the funds have been spent more efficiently elsewhere? In the next section, the opportunity cost of the funds allocated to the criminal justice system will be discussed.

\subsection{Methodology: opportunity cost}

The criminal justice system occupies resources that could have been utilised more productively elsewhere in the economy. Was too much spent on the criminal justice system for the purpose of controlling crime during the period 1980-2006? This section will attempt to indicate what the opportunity cost was in terms of foregone expenditure on social services.

If the rate of increase in the government's expenditure on the South African criminal justice system is compared with the rate of increase in government expenditure on social services, it is clear that for most of the period 1980-2006 the former outpaced the latter. The array of possibilities that could have been realised had the resources allocated to the criminal justice system, or part thereof, been allocated differently, e.g. allocated to social services, will be quantified. This may explain why the government has failed to meet the huge demand for the basic needs of the 
majority of South Africa's people. The level of social expenditure on whites during the apartheid era was too high to be extended to other groups (Van der Berg, 1989:200). As a result of limited financial resources it was impossible to maintain the expenditure level that whites enjoyed prior to 1994 and to uplift other groups to the same level of expenditure. This has resulted in a social expenditure dilemma.

The magnitude of the figures presented in the previous section becomes far more apparent when considering what could have been done with the funds had they been allocated elsewhere in the economy. In order to determine the impact the funds could have had if spent differently it is important to determine how much of the expenditure on the criminal justice system can be regarded as excessive, i.e. assuming that a certain amount of expenditure is necessary.

There must be a norm beyond which government expenditure can be regarded as excessive. Two approaches to determining this norm have been adopted. The inflation approach assumes that expenditure on the criminal justice system increases with the inflation rate, whereas the social services scenario views the rate of growth of social expenditure by government for the period 1980-2006 as the yardstick. In sections 3.3.2 and 3.3.3 it will be shown that government expenditure on the South African criminal justice system has been excessive in terms of both these norms.

In quantifying the opportunity costs involved in expenditure on the criminal justice system, two of South Africa's main social expenditure categories of need will be used: education and housing. The choice of these two variables for calculating an opportunity cost was based on research results indicating that education and housing are two of the most significant determinants in affecting change in crime patterns. Empirical research by Brown (2001), for example, indicated that education is the most important economic explanatory variable for crime prevention and that urbanisation is the most important socioeconomic variable. The next section will outline the shortages in these two categories.

\subsubsection{Shortage of schooling and housing facilities}

Although it is difficult to pinpoint a specific time when the shortages in schooling and housing facilities should be evaluated, the authors decided to use the backlogs that existed after the African National Congress took over political power in 1994. The core issue relating to opportunity cost in the field of education is the lack of educational facilities. According to the former Minister of Education Mr Sibusiso Bengu (in South African Institute of Race Relations, 1996:116), there was a shortage of 85200 classrooms at the beginning of 1995. It should be kept in mind that this shortage excluded facilities such as toilets, administration blocks and laboratories. The shortage in classrooms was then converted to a shortage in schools.

The number of enrolments at primary schools as a percentage of the total number of enrolments in 1995 was used as a pro rata estimate for the shortage in primary school classrooms (Research Institute for Education Planning, 1995:4). The same procedure was followed to estimate the shortage in secondary school classrooms. Given a classroom learner ratio of 1:40 for primary schools and 1:35 for secondary schools, it was calculated that there was a shortage of 2054 primary schools and 914 secondary schools in 1995 (as indicated in Table 5).

In terms of the cost per primary school (R30 million) and per secondary school (R35 million), the shortage could have been eliminated at a total cost of approximately R93.6 billion. Crouch (in South African Institute of Race Relations, 1996:144) estimated the cost of providing the toilets needed in all schools at a ratio of 20 learners per toilet at R8 billion in 1995. If this is adjusted using the building index of the Bureau for Economic Research (Building index electronically received from $\mathrm{Mr}$ Snyman, 2007) it converts to R22.8 billion in 2006 prices. The total costs of eliminating the shortage in schools would be approximately R116.4 billion. 
Table 5

Number of schools needed in South Africa in 1995

\begin{tabular}{|l|c|c|}
\hline & Primary schools (1:40) & Secondary schools (1:35) \\
\hline Classrooms needed & 56474 & 28726 \\
\hline Learners in need & 2258960 & 1005410 \\
\hline Schools needed (1 100 learners per school) & 2054 & 914 \\
\hline
\end{tabular}

Source: South African Report, various issues, Research Institute for Educational Planning, 1995:4 and South African Institute for Race Relations, 1996:116.

In 1995 it was estimated that 2.18 million new houses would have to be built to alleviate the shortage of houses in South Africa (South African Institute for Race Relations, 1996:335361). Allowing for the present direct cost of building a house (excluding the cost of land) of R48 700 (Department of Housing, 2007) the total cost of alleviating the housing shortage amounts to R106.2 billion.

\subsubsection{Inflation scenario: Government expenditure on the criminal justice system increases with the inflation rate.}

In this scenario the inflation rate is used as a yardstick for determining whether government expenditure on the criminal justice system has been excessive. Any increase in actual government expenditure from 1980 above the inflation threshold is then regarded as excessive.

If the annual inflation rates for the period 1980-2006 are taken as the appropriate rates of increase in government expenditure on the criminal justice system, it indicates an excessive amount of approximately
R288 billion (South African Reserve Bank, various issues). The extent of this excess becomes increasingly clear when the figure is translated into the number of houses or schools that could have been built. As explained in the previous section, the total cost of eliminating backlogs of classrooms and toilet facilities in the schooling system amounts to R116.4 billion. To provide the backlog of 2.18 million houses would cost an additional R106.2 billion. This means that if the excess spent on the criminal justice system was, instead, devoted to schools and housing, there would have been no current shortage, and an additional amount of R65.4 billion would still have been available for spending on other social services (See Table 6). This becomes even more apparent if the current backlog of 2.4 million houses in South Africa is taken into account (Naidoo, 2007:72), an indication that the situation is deteriorating. Clearly, the opportunity cost of excess spending on the criminal justice system was substantial in terms of the social services that could have been financed instead.

Table 6

Opportunity cost of overspending on the criminal justice system

\begin{tabular}{|c|c|c|c|c|c|}
\hline \multirow[b]{2}{*}{ Opportunity cost } & \multirow[b]{2}{*}{$\begin{array}{l}\text { Shortage of } \\
\text { schools and } \\
\text { houses }\end{array}$} & \multicolumn{2}{|c|}{ Inflation scenario } & \multicolumn{2}{|c|}{ Social services scenario } \\
\hline & & $\begin{array}{l}\text { (Number of } \\
\text { schools/houses } \\
\text { that could have } \\
\text { been built) }\end{array}$ & $\begin{array}{l}\text { Percentage of } \\
\text { backlog } \\
\text { eliminated }\end{array}$ & $\begin{array}{c}\text { (Number of } \\
\text { schools/houses } \\
\text { that could have } \\
\text { been built) }\end{array}$ & $\begin{array}{c}\text { Percentage of } \\
\text { backlog } \\
\text { eliminated }\end{array}$ \\
\hline \multicolumn{6}{|l|}{ Schools $^{1}$} \\
\hline Primary & 2054 & 2054 & $100 \%$ & 2054 & $100 \%$ \\
\hline Secondary & 914 & 914 & $100 \%$ & 914 & $100 \%$ \\
\hline Housing units ${ }^{2}$ & 2180000 & 2180000 & $100 \%$ & 445638 & $20.5 \%$ \\
\hline Excess amount available & & R65.4 billion & & - & \\
\hline \multicolumn{6}{|l|}{2 Housingunits. } \\
\hline $\begin{array}{l}2 \text { Housing units: } \\
\text { Current building cost of }\end{array}$ & & (n) & & & \\
\hline
\end{tabular}




\subsubsection{Social services scenario: Government expenditure on the criminal justice system increases at a rate equal to the increase in government expenditure on social services.}

The second yardstick used is the rate of increase in government expenditure on social services (education, health, housing, social security and welfare). Government expenditure on social services increased at an average annual rate of approximately 21 per cent for the period 1980-1995. For the period 19952006, the growth rate at just under 13 per cent per annum (South African Report, 1985-1997 and National Treasury, 1998-2006) was considerably lower. These average growth rates are higher than the inflation rates for the respective periods. The average expenditure on social services was used because the reason for government's expenditure on curtailing crime and violence is maintaining social peace. Social expenditure has at its core the same goal. The rationale adopted is that there is no reason why government expenditure as an indirect attempt to maintain social peace should exceed a direct attempt at attaining the same goal. The rate of increase in the expenditure on social services should thus not differ greatly from that of the criminal justice system. At the same time, it should be borne in mind that, apart from the fact that empirical research has established that expenditure on education and housing are far more significant deterrents to crime vis-à-vis direct expenditure on the criminal justice system, research results have also revealed that expenditure on education and housing are the two most significant deterrents to crime. Table 6 indicates that, even if government expenditure on the criminal justice system had increased at the same rate as that on social factors, a substantial opportunity cost would still have been involved.

If government expenditure on the criminal justice system since 1980 had increased at the same rate as that on social expenditure, R138.2 billion could have been saved. In other words the shortage in primary and secondary schools could have been eliminated. Simultaneously, 447638 house (20.5 per cent of the shortage) could also have been financed.

Both these scenarios illustrate the significant opportunity costs involved. At the heart of the argument is the age-old dilemma: Too many guns, too little butter. In an attempt to combat crime, the South African government allocated funds to the upkeep of the criminal justice system, of which a substantial amount could have been used to finance much-needed social services.

\section{4}

\section{Conclusion}

An attempt to compare South African crime statistics with those of other countries to ascertain whether the crime situation is improving or deteriorating proved to be a taxing exercise. This is partly because the South African government placed a moratorium on the release of criminal statistics in 2000, which obscures such comparisons. However, according to the information available, the results of this study clearly demonstrate that South Africa, in comparison with other middle and lower-income countries that are plagued by high crime rates, is the worst afflicted. It is also clear that, when comparing the pre- and post 1994 situation, the crime situation in South Africa has deteriorated. Such a comparison is imperative in establishing whether the South African government is winning its fight against crime, i.e. whether current policy vehicles are effective in combating crime, or whether the government ought to take heed of the research results and alter its approach to combating crime. The research results reveal that the South African government, which is responsible for implementing an action plan against crime, is failing in this respect, showing itself to be an incompetent agent of the people it is supposed to govern.

The main emphasis of the research was on quantifying the excessive extent of government expenditure on the criminal justice system. No evidence of such an exercise could be traced in the literature, especially not in the calculation of the opportunity cost involved in terms of foregone expenditure on social services. This is a key policy vehicle for social development 
in a developing country. The research results contribute first to the more effective administration of appropriate policy vehicles to facilitate the combating of crime; and, secondly, to the enhancement of social development, a key social deliverable in South Africa. In particular, the need to address the housing and schooling shortages as a policy vehicle for combating crime has been well-established by empirical research. Consequently, the opportunity cost calculation in this study was expressed in terms of the houses and schools that could have been built with the excess funds allocated to the criminal justice system. This is even more evident if one considers that empirical research clearly indicates that direct expenditure on the criminal justice system is the least significant explanatory variable in combating crime.

The criminal justice system, which has been tasked with addressing the crime problem, currently costs the South African government approximately R45.2 billion per annum. Funds allocated to the upkeep of the criminal justice system are non-productive in nature and are desperately needed in other sectors that contribute directly to economic growth.

Has the government spent too much on criminal justice? Government expenditure on the criminal justice system cannot be regarded as excessive per se. There must be a specific level of funds that the government is required to spend on the criminal justice system. Both yardsticks used in this paper, the inflation rate and the rate of increase in expenditure on social services indicate that the government's expenditure on criminal justice has been excessive.

Both the inflation scenario and the social services scenario were compared with actual government expenditure on the South African criminal justice system. It was indicated that for the period 1980-2006 the South African government could have saved more than R288 billion according to the inflation scenario, and approximately R138 billion according to the social services scenario. After considering the needs in the field of education, both scenarios indicated that the current backlog could have been prevented had these opportunity cost funds been allocated differently. It was further shown that according to the inflation scenario the housing shortage could also have been eliminated and an additional amount of R65 billion would still have been available for expenditure on other social services. In accordance with the social services scenario, both the schooling shortage and 21 per cent of the housing shortage could have been met.

In conclusion, it was shown that South Africa's crime rate is high by global comparison. It was also shown that South Africans suffered considerable opportunity costs in terms of foregone social services expenditure as a result of the high crime rate. More specifically these opportunity costs involved two of the major social services need areas in South Africa: education and housing. Ironically, empirical research has shown that education and housing are also two of the most significant determinants of change in the crime rate.

\section{Endnotes}

1 The study by Blackmore did not account for the possible dual causality or endogeneity, and some of the explanatory variables are likely to be highly correlated, which could have led to multi-colinearity. The time series is also assumed to be stationary, without any evidence that this is the case. If instrumental variables and co-integrating panel estimators were used, it may have led to different conclusions about the size and significance of the influence of expenditure on ordinary crimes.

2 It can be argued that the development of the security industry could be seen as a positive spill-over effect of the high crime rate in South Africa. However, an industry whose existence depends on the high incidence of crime can hardly be seen as a positive development. 


\section{References}

BECKER, G.S. 1968. Crime and punishment: An economic approach. Journal of Political Economy, 76(2):169-217.

BEZUIDENHOUT, M.M., JOUBERT, G., HIEMSTRA, L.A. \& STRUWIG, M.C. 2009 Reasons for doctor migration from South Africa. South African Family Practice, 51(3):211-215.

BLACKMORE, F.L.E. 2003. A panel data analysis of crime in South Africa. South African Journal of Economic Management Sciences, 6(3):439-458.

BROWN, K.V. 2001. The determinants of crime in South Africa. The South African Journal of Economics, 69(2):269-298.

BUONANNO, P. 2003. The socioeconomic determinants of crime: A review of the literature. Working Paper 63, University of Milano-Bicocca.

CLARK, G., EIFERT, B., HABYARIMANA, J., INGRAM, M., KAPERY, W., KAPLAN, D., SCHWARTZ, M. \& RAMACHANDRAN, V. 2005. South Africa: An assessment of the investment climate. African Private Sector Group, World Bank Publication.

CRIME INFORMATION MANAGEMENT CENTRE. 1994. Interpol report: International crime statistics. SAPD: Pretoria:1-6.

DEMOMBYNES, G. \& ÖZLER, B. 2002. Crime and local inequality in South Africa. Washington: World Bank:1-35.

DEPARTMENT OF FINANCE. (Various issues) National Expenditure Survey (1998-2000 issues).

DEPARTMENT OF HOUSING. 2007. Subsidy information (2006/07 financial year), Available [online] at http://www.housing.gov.za.

EYEWITNESS NEWS. Cele criticised for supporting stats moratorium. Available [online] at http://www.eyewitnessnews.co.za.

HARRIES, J. 2007. Law and crime in the Roman world. Cambridge: Cambridge University Press. INSTITUTE FOR SECURITY STUDIES. 2007. South African crime statistics per category, Available [online] at http://www.issafrica.org.

LOWENBERG, A.D. \& KAEMPFER, W.H. 2001. The origins and demise of South African Apartheid: A public choice analysis. Michigan: University of Michigan Press.

LUIZ, J.M. 2001. Temporal association, the dynamics of crime, and their economic determinants: A time series econometric model of South Africa. Social Indicators Research, 53:33-61.

MUNCHIE, J. 2001. The construction and deconstruction of crime, In MUNCHIE, J. \& MCLAUGHLIN, E. (ed.) 2001. The problem of crime, London: Sage Publications Ltd:7-23.

NAIDOO, P. 2007. Housing: Long road ahead. Financial Mail, 16 November:72-73.

NATIONAL TREASURY. (Various issues) National Budget Review (1998-2006 issues).

NATIONAL TREASURY. (Various issues) Estimates of National Expenditure (2001-2007 issues).

RESEARCH INSTITUTE FOR EDUCATIONAL PLANNING. (Various issues) Education and manpower development (1995 and 1996 issues). Bloemfontein: University of the Orange Free State.

SOUTH AFRICAN INSTITUTE OF RACE RELATIONS. (Various issues) Race Relations Survey (1994/95 and 1995/96 issues). Cape Town: Calvin \& Sales.

SOUTH AFRICAN INSTITUTE OF RACE RELATIONS. (Various issues) South Africa Survey (1997/98 2005/06 issues). Cape Town: Creda Communication.

SA'S SHORT-TERM INSURANCE INDUSTRY CONTRIBUTES TO THE FIGHT AGAINST CRIME. 2006. South African Insurance Times \& Investment News, December.

SOUTH AFRICAN REPORT. (Various issues) Republic of South Africa - Estimates of expenditure (Issues from 1979/80 until 1996/97). Pretoria: Government Printer.

SOUTH AFRICAN RESERVE BANK. (Various issues) Quarterly Bulletin (1985-2007 issues).

STATISTICS SOUTH AFRICA. (Various issues) Mid-year population estimates (Issues from 1980 - 2006). Available [online] at http://www.statssa.gov.za/publications.

STONE, C. 2006. Crime, justice and growth in South Africa: Towards a plausible contribution from criminal justice to economic growth, CID Working Paper No 131, August. 
THE WORLD BANK. 2006. World development indicators (CD-ROM), Washington, D.C.: World Bank Publications.

VAN DER BERG, S. 1989. Long term economic trends and development prospects in South Africa. African Affairs, April:180-203.

VAN ROOYEN, J. 2000. The new Great Trek: The story of South Africa's white exodus. Pretoria: Unisa Press.

UNITED NATIONS OFFICE ON DRUGS AND CRIME. 2004. Seventh United Nations survey on crime trends and operations of criminal justice systems, Available [online] at http://www.unodc.org.

WILLIAMS, K.S. 2001.Textbook on criminology. Oxford: Oxford University Press. 